\title{
Soil Quality Attributes Induced by Land Use Changes in the Fincha'a Watershed, Nile Basin of Western Ethiopia
}

\author{
Getahun Kitila $^{1^{\star}}$, Heluf Gebrekidan ${ }^{2}$ and Tena Alamrew ${ }^{3}$ \\ ${ }^{1}$ College of Natural and Computational Sciences, Wollega University, Post Box No: 395, Nekemte, Ethiopia \\ ${ }^{2}$ School of Natural Resource and Environmental Sciences, Haramaya University, Post Box No: 138, \\ Dire Dawa, Ethiopia \\ ${ }^{3}$ Institute of Technology, Haramaya University, Post Box No: 138, Dire Dawa, Ethiopia
}

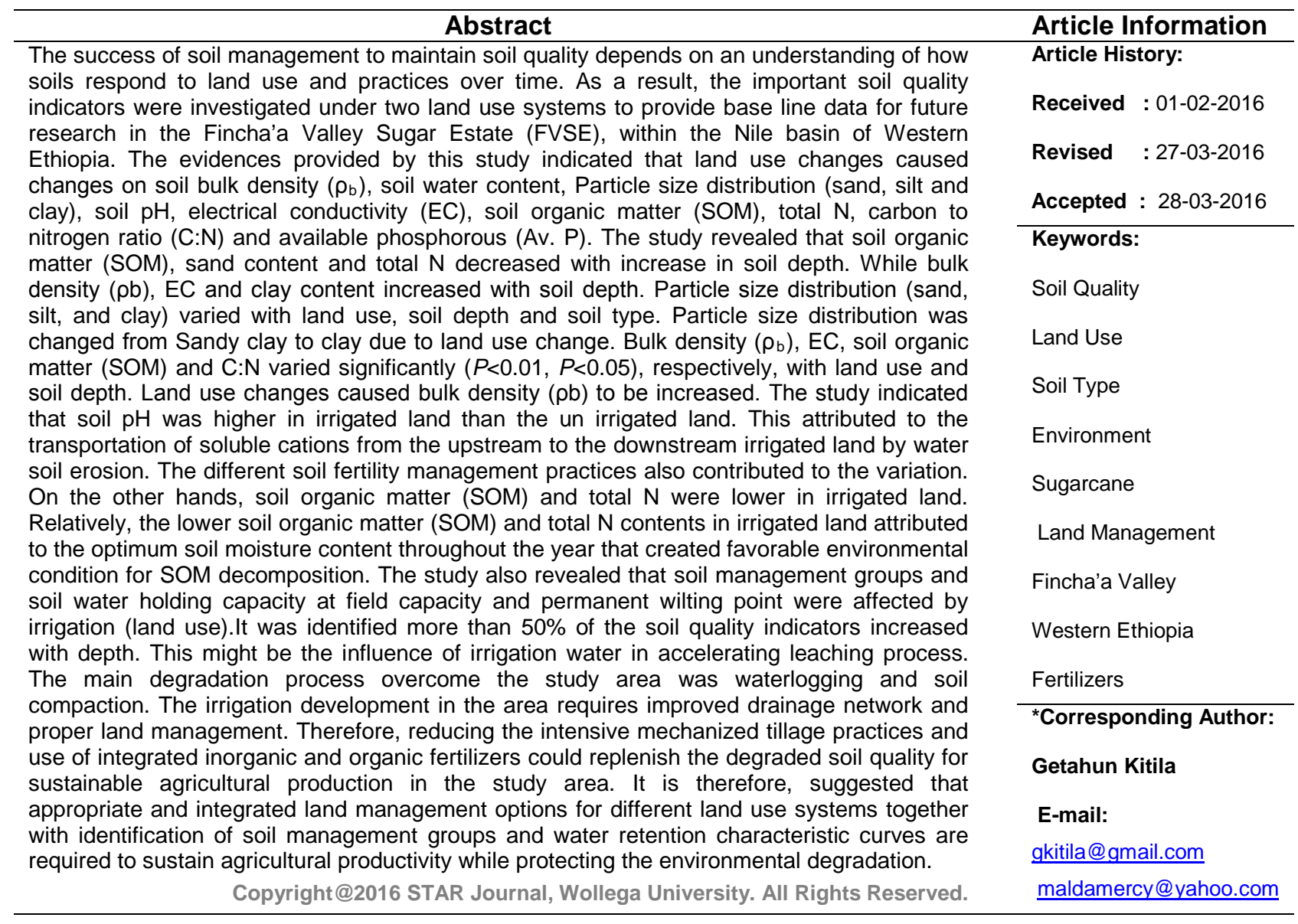

\section{INTRODUCTION}

The complex integration of the primary natural resources, soil, water and vegetation, is vital for maintaining terrestrial ecosystem functions and productivity (Islam and Weil, 2000). Increase in population and cultivated land have led to an indiscriminate exploitation of natural forests and fragile land for agriculture. Soil organic matter (SOM) and soil nutrient depletion being among the major forms of soil degradation
(Golestan, 2005). Land use/land cover changes that involve conversion of natural forests to farmland and open grazing are widely practiced in the highland of Ethiopia. The effects of such landuse/land cover changes on natural resources of the country, particularly land degradation through soil erosion, have been reported in scientific studies (Hajabasi et al., 2007; Yousefifard et al., 2007; Khormali etal., 2009; Majliwa et al., 2010). Land 


\section{Getahun Kitila et al.,}

use/land cover changes have impacts on the atmospheric and subsurface-components of the hydrological cycle (Scanol et al., 2005). They can alter the balance between rainfall, evaporation and infiltration and, consequently, the area's run-off response (Costa et al. 2003; Jiang et al., 2008). The destruction of tropical natural forests is a major concern, as it has a cumulative impact on biodiversity, regional and global climate, and soil productivity (Lambin et al., 2003).

The massive soil loss in the country is caused by its' susceptibility to erosion due to the mountainous landcape coupled with mismanagement, intense rainfall and cultural practices of the farming community that leave the soil bare after harvest (Tadesse, 2002). It is usually considered to have three main aspects reflecting physical, chemical, and biological soil properties and is important for assessment of land degradation and for identification of sustainable land use practices (Dexter, 2004; Singh et al., 2009). The main consequences of inappropriate land use changes are land degradation and soil quality deterioration through loss of vegetative cover, top soil moisture, infiltration capacity, water storage, soil organic matter (SOM), agrochemicals chemicals, resilience, natural regeneration capacity, and a lower water table, factors that are critical for soil health (Khormadali et al., 2007). Land use and land management effects on soil quality have been documented particularly in relation to soil degradation and restoration in North West Thailand (Vityakon et al., 2007), visitors activities and management on the surface soil (Yukesh et al., 2010) and effect of long term cultivation (Ozgoz et al., 2011) in Turkey, and the influence of culitivated management systems on soil biological quality in Spain (Garcia-Orenes et al., 2012). Land use and management are influencing soil properties. While unsuitable agricultural practices can cause soil erosion, on the contrary use of cover can reduce risk of erosion (Garcia-Orenes et al., 2009; Garcia-Orenes et al., 2010). The concept of soil losses due to erosion is closely linked with processes of soil chemical (loss of nutrients through vegetation removal, erosion, leaching), physical and biological degradations (decline in soil organic matter (SOM) content) (Eyasu, 2002). Soil degradation in this article refers to the reduction in soil quality due to irrigation development and various human managements. It is this variability of human activities (biomass burning, application of fertilizer, transfer of species, plowing the land etc.,) that are important immediate sources of the soil physical and chemical properties change in Ethiopia (Taddesse, 2002).

The rate and extent of soil degradation through human influence is situation specific. For instance, soils of a given locality, which may have experienced similar pedogenic processes, can be differentially affected depending on the intensity of land use activities exercised. Thus, susceptibility of soils to degradation must be separately assessed for each biophysical and socioeconomic setting (Mesfin, 1998). In Ethiopia, very few studies (Mulugeta, 2004; Teklu et al., 2004; Wakene and Heluf, 2004; Yifru and Taye, 2011; Acahlu et al., 2012; Fekadu et al., 2012; Tadele et al., 2012) have considered the effects of different land use/land cover changes, and their associated soil management practices, on soil physical and chemical properties. Ethiopia being a large country with large biophysical and socio economic diversity, these previous studies has been less than
Sci. Technol. Arts Res. J., Jan-March 2016, 5(1): 16-26

adequate to describe the extent of soil degradation associated to land use/land cover changes in the country.

Productivity of the cultivated land has been reduced as a result of declining of soil fertility; poor irrigated land management and miss use of water for irrigation. The success of soil management to maintain soil quality depends on the understanding of how soils respond to land use and practices over time (Wakene and Heluf, 2004). Although, most of the irrigation water sources are less likely to have adverse impact on soils in arid and semi-arid agro ecosystems, generating scientific information has paramount importance for sustaining the production and productivity of the irrigation system in sugarcane plantation field in the Fincha'a Valley Sugar Estate, Nile Basin of western Ethiopia. Therefore, this study was carried out with the objective to assess the effects of land use change on soil quality attributes and to compare the outcomes against the soil properties.

\section{MATERIALS AND METHODS}

\section{Geographical Environment of the Study Area}

Fincha'a watershed is located in the western highland of Ethiopia, within the Nile basin, Ethiopia and bounded by the Amhara National Regional State in the north, Guduru District in the South and East, Horro District in the west and Jarte and Amuru District in the North West (Figure .1). It lies between $1055000 \mathrm{~m}$ and $1109500 \mathrm{~m} \mathrm{~N}$ and 302000 and $338000 \mathrm{~m} \mathrm{E}$. The elevation in the watershed varies from 892 to 2520 meters above sea level (masl). The littoral and alluvial deposits of recent sediments underlie the area (Getahun et al., 2013b). Fincha'a River originates from the Chomen and Fincha'a swamps on the highland and divides the scheme into west and east banks and joins the Nile River of Western Ethiopia. Many streams join the Fincha'a River, the main tributaries being Agamsa, Korke, Fakaree, and Boye from the western side and Sargo-Gobana, Aware, Sombo, and Andode from the eastern side (Getahun et al., 2013b).

The thirty two years (1979-2011) climatic data from the FVSE Meteorological Station recorded a yearly average rainfall of $1315 \mathrm{~mm}$ (Figure 2) which is characterized by unimodal rainfall pattern. About $80 \%$ of the annual rain falls between May to September. Its mean annual maximum and minimum temperatures are 30.5 and $14.8^{\circ} \mathrm{C}$, respectively (Figure 4. 2). The average annual relative humidity is about $84 \%$ (Seleshi et al., 2007). The FVSE has alternate wet (during May to October) and dry (during the rest of the months) seasons. Wind speed in the FVSE is low as the surrounding escarpments hinder wind movement. However, wind speed is high between the months of March to June (Worku, 1995; Ademe, 2001 and Amhed, 2007). The soils in the FVSE are made of alluvia land colluvial materials from the surrounding escarpments (Bezuayehu, 2008). Six major soil types were identified in the FVSE areas of which Luvisols and Vertisols are predominant (Getahun et al., 2013a). These soils account for more than $95 \%$ of the cultivated and irrigated land.

As indicated in the figure 3 , maximum rainfall in the area is obtained in July while minimum rainfall is on January. Furthermore, the rainy season in the area is summer while winter is the dries season. 


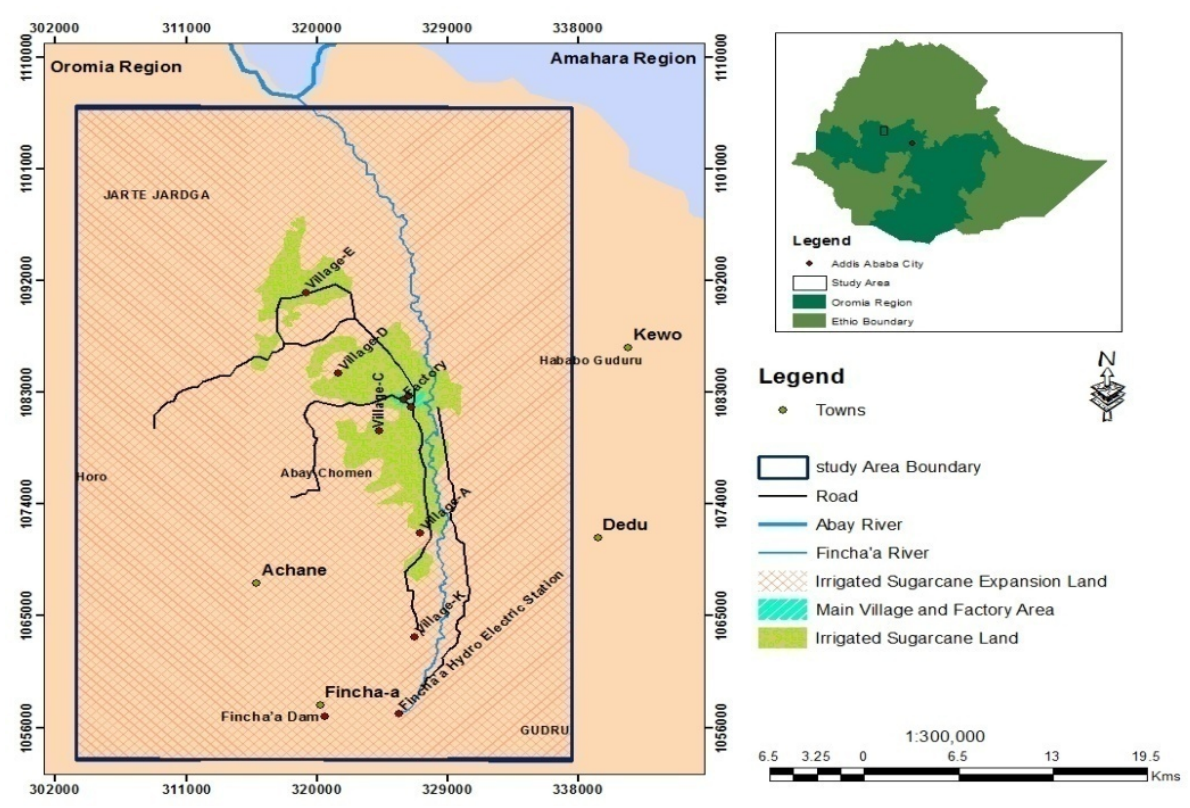

Figure 1: Location Map of the Study Area

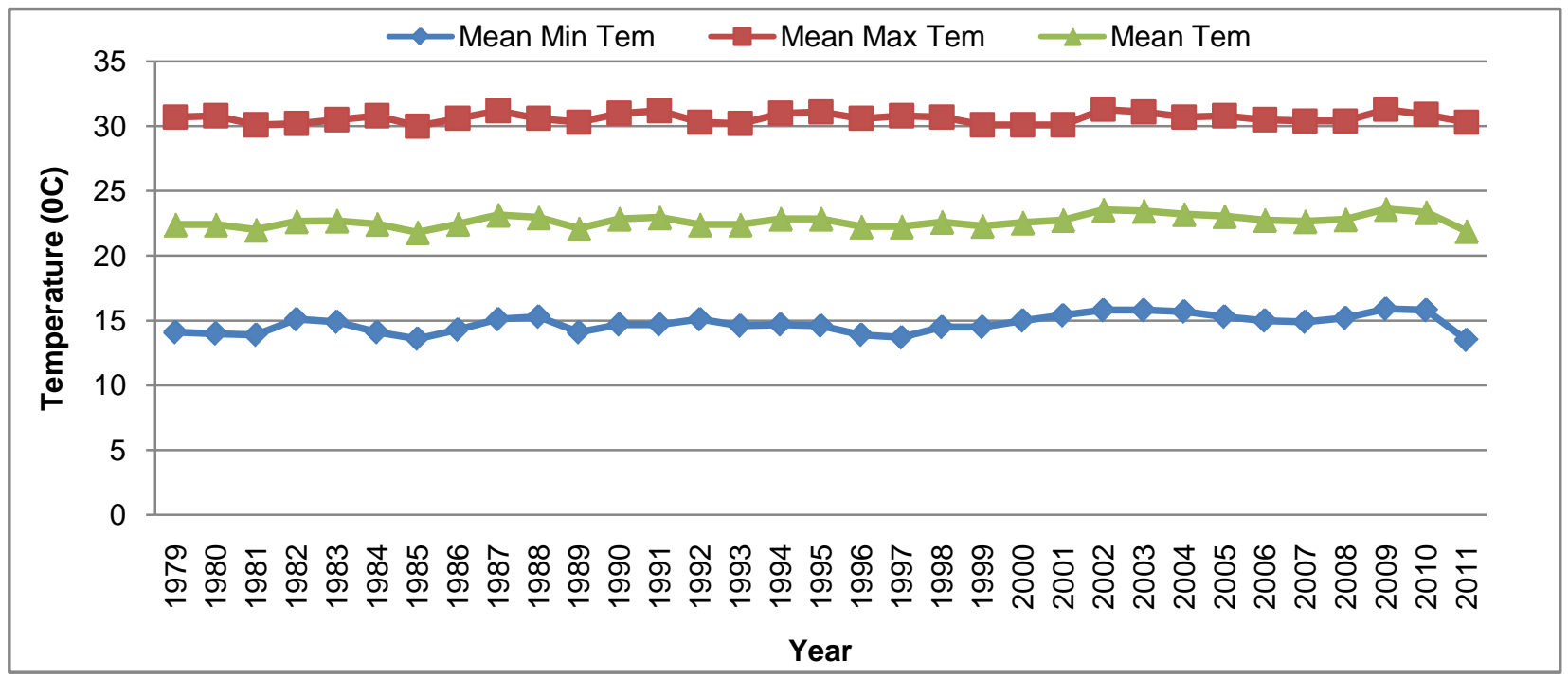

Figure 2: Mean, Mean Minimum and Mean maximum Temperature of the Study Area

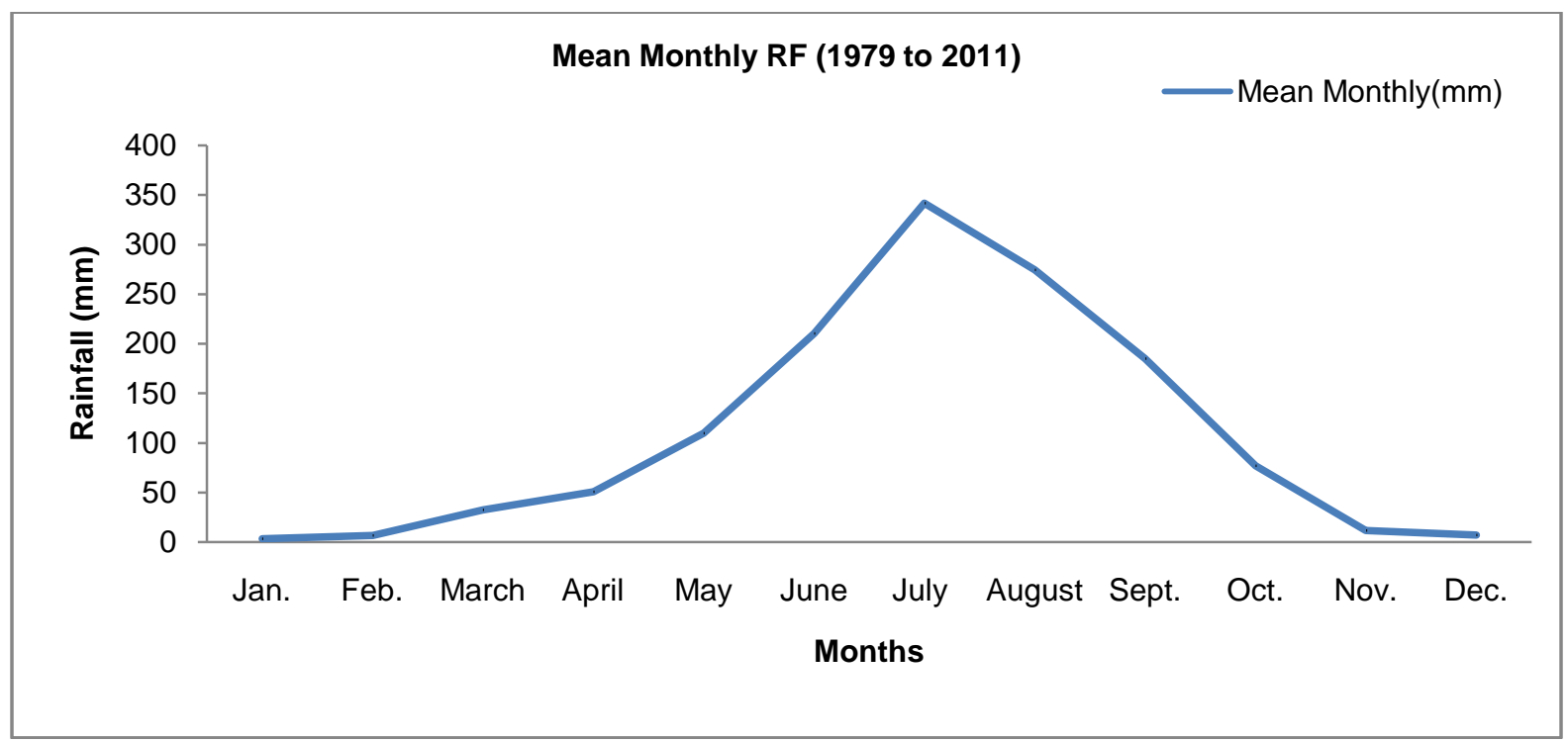

Figure 3: Mean Monthly Rainfall for the year 1979 to 2011. 
Getahun Kitila et al.,

\section{Soil Sampling and Analysis}

Soil samples from (0-30, 30-60 and 60-90) cm depth were collected in April 2011 from ninety (90) randomly selected irrigated and unirrigated land, using a hand auger for analysis of selected physical and chemical soil properties to be used as soil quality indicators under the irrigated and unirrigated use types. . In total, 270 samples were collected, air-dried and passed through a $2 \mathrm{~mm}$ sieve to remove stones, roots, and large organic residues before conducting analyses for chemical and physical characteristics. Both disturbed and undisturbed core soil samples were collected. The disturbed soil samples were, air dried ground and passed through a $2 \mathrm{~mm}$ sieve to remove stones, roots, and large organic residues before conducting analyses for chemical and physical characteristics. The undisturbed soil samples collected were using a core sampler which were weighed at field moisture and after drying the pre-weighed soil core to constant weight in an oven at $105^{\circ} \mathrm{C}$ as per the described by (Day,1965).

Soil particle size distribution was carried out following the modified sedimentation hydrometer method procedure (Bouyoucos, 1951) as described in (Day, 1965). Bulk density and particle density were determined by core method as described in (Blake and Hartge, 1986a) and pycnometer method (Blake and Hartge, 1986b), respectively. The soil water holding capacity value was measured at $-1 / 3$ bar for field capacity and -15 bar for permanent wilting point using pressure plate apparatus (Klute and Dirksen, 1986), while available water holding capacity was calculated as difference in water content at field capacity and permanent wilting point. Total porosity was estimated from the bulk and particle densities as described as:

$$
\operatorname{TP}(\%)=\left(1-\rho_{\mathrm{b}} / \rho_{\mathrm{s}}\right) \times 100
$$

Where, $\rho b$ bulk density in $\left(\mathrm{g} \mathrm{cm}^{-3}\right)$ and $\rho_{\mathrm{s}}$ particle density $\left(\mathrm{g} \mathrm{cm}^{-3}\right)$.

Soil moisture content was measured after drying at $105{ }^{0} \mathrm{C}$ overnight (Gardner, 1986). Saturated hydraulic conductivity was measured in situ on the surface layer using Guelph permeameter and Double ring infiltrometer was used to determine the infiltration rate (Lowery et al., 1996). Soil pH was determined potentiometrically in 1:2.5 soils: water suspension using a combined glass electrode $\mathrm{pH}$ meter. The electrical conductivity (EC) of soil was measured from paste extract as described by Sahelemedin and Taye (2000). Organic carbon was determined by the wet digestion method (Walkley and Black, 1934). Total $\mathrm{N}$ was determined using the microKjeldahl digestion, distillation and titration procedure as described by Bermer and Mulvaney (1982). Available P in the soil samples was extracted by using Bray II or the Olsen (1982) methods (Baruah and Barthakur, 1997) depending on the $\mathrm{pH}$ of the soil.

\section{Statistical Data Analysis}

The significance difference of means of soil quality indicators with land use types and soil depth was tested using analysis of variance (ANOVA) following the general linear model $(\mathrm{GLM})$ procedure at $(P<0.05)$ using SAS 9.2 software (SAS, 2004). Tukey's honest significance difference (HSD) test was used for separation when analysis of variance showed statistically significant differences $(P<0.05)$.
Sci. Technol. Arts Res. J., Jan-March 2016, 5(1): 16-26

\section{RESULTS AND DISCUSSION}

\section{Implication of Land Uses on Soil Physical Properties in the Study Area}

The results of selected soil physical properties under different land use are presented in Table 1. Particle size distribution is an intrinsic soil property, but intensive cultivation contributed to the variations in particle size distribution at the surface soil of the irrigated land. This could be due to the removal of soil particles through sheet and rill erosion, and mixing of the surface and subsurface soil layers during deep tillage activities. Generally the particle size distribution of the soils in all locations ranged from sandyclay to clay. This might be due to long-term effect of pedogenesis processes such as erosion; deposition, eluviation, weathering and cultivation. However, such soils are known to be suitable for irrigated sugarcane plantation with cautious soil management.

The sand content was significantly $(P<0.01)$ varied with soil type. The difference was statistically significant $(P<0.05)$ with land use, soil depth. The proportion of sand content was higher for unirrigated land use as compared to irrigated land use (Table 1). The higher sand content is probably due to high amount of rainfall in the area that washes away the finer soil particles leaving behind the sand fractions (Table 1).

Silt content was not statistically significant with land use, soil type, soil depth $(P>0.05)$. Clay content was statistically significant $(P<0.01)$ with soil type, land use. However, clay content did not show any significant variation with soil depth $(P>0.05)$. The clay content increased whilst the sand decreased from the surface to the subsurface soil layers in all land use systems (Table 1). The higher clay content in irrigated than unirrigated land use system might be due to the fact that cultivation (irrigation) promotes further weathering processes as it shears and pulverizes the soil and changes the moisture and temperature regimes (Yimer et al., 2006).

The higher clay content in subsurface soil layer than in the top soil layer may indicate possible clay translocation from the top soil layers to the bottom layer. The increase in clay content with increasing depth and the lowest overall mean proportion of clay content compared to the sand and silt contents concurs with the results of other studies (Sintayehu, 2006; Yimer et al., 2006). Considering the three soil depth, higher mean clay content $(66 \%)$ was observed within the subsurface soils layers of irrigated Vertisols (Table 1). This is implication of effect of irrigation on Vertisols. Opposite to clay, higher sand content (40\%) was found in the top soil layer of unirrigated Luvisols. This may be due to the intensive and continuous cultivation which might cause compaction on the top soil layer that reduces translocation of clay particles within the different layers and due to mixing up by tillage activities in agreement with the findings reported by (Jaiyeoba, 2001; Wakene and Heluf, 2001). The highest values of both sand $(40 \%)$ and silt $(11 \%)$ contents were recorded at the top $(0-30 \mathrm{~cm})$ soil layer of the unirrigated land while clay content was highest $(66 \%)$ at the subsurface $(60-90 \mathrm{~cm})$ soil layers of the irrigated land (Table 1). On the other hand, the lowest values of sand and silt contents was observed in both the top and subsurface soil layers of the irrigated land with the exception of the two soil depth in the irrigated land, which had the same clay content the clay contents of the remaining treatment combinations were significantly different $(P \leq 0.05)$ from each other due 


\section{Getahun Kitila et al.,}

to land use and soil depth. This implies that increase in clay content significantly increases the FC, PWP and AWHC in the soil, but decreased the proportion of sand silt and soil organic matter analysis of variance of bulk density $\left(\rho_{b}\right)$ of the studied soils showed significant variability with respect to land use and soil depth at $(P<0.01)$, (Table 1). However, bulk density $\left(\rho_{\mathrm{b}}\right)$ did not show any significant variation with soil type $(P>0.05)$.

The bulk density $\left(\rho_{b}\right)$ of different land uses, varied from 1.24 (unirrigated Luvisols) to $1.26 \mathrm{~g} \mathrm{~cm}^{-3}$ (unirrigated Vertisols) for surface soil layers $(0-30 \mathrm{~cm})$ depth and 1.29 (unirrigated Luvisols) to $1.28 \mathrm{~g} \mathrm{~cm}^{-3}$ (unirrigated Vertisols) for $(30-60 \mathrm{~cm})$ soil depth. In general, bulk density $\left(\rho_{\mathrm{b}}\right)$ increased with soil depth for all land uses. Bulk density $\left(\rho_{\mathrm{b}}\right)$ increased from 1.24 to $1.29 \mathrm{~g} \mathrm{~cm}^{-3}, 1.26$ to $1.28 \mathrm{~g} \mathrm{~cm}$

for unirrigated (Luvisols and Vertisols) land use, respectively. This higher value of bulk density $\left(\rho_{b}\right)$ at the sub surface soil depth for unirrigated (luvisols) and (Vertisols) land use may have been due to compaction of soil due to higher moisture content down the soil profile.

The bulk density $\left(\rho_{b}\right)$ value increased from 1.32 to $1.38 \mathrm{~g} \mathrm{~cm}^{-3}$ and 1.32 to $1.39 \mathrm{~g} \mathrm{~cm}^{-3}$ for irrigated (Luvisols and Vertisols) land use, respectively. The high bulk density $\left(\rho_{b}\right)$ under cultivated/irrigated land was due to the trampling effects and irrigation/land use change. This result is in harmony with the research findings reported by (Wakene and Heluf, 2004; Yihenew and Getachew, 2013). The bulk density $\left(\rho_{b}\right)$ of irrigated Vertisols was $1.39 \mathrm{~g} \mathrm{~cm}^{-3}$ greater than that of irrigated Luvisols $1.38 \mathrm{~g}$ $\mathrm{cm}^{-3}$ at the subsurface soil layer $(60-90 \mathrm{~cm})$.

This is the implication of the effect of moisture content, clay content and soil organic matter on bulk density $\left(\rho_{b}\right)$ of irrigated soils. This might be due to the softy nature of Vertisols as compared to Luvisols at the subsurface soil layer. The bulk density value of irrigated land was greater than the value for unirrigated land. In unirrigated land, there was relatively higher soil organic matter making the soil loose, porous and surface compaction due to use of heavy trucks and machinery on undisturbed cohesive soils that were not under irrigation that might have reduced the bulk density. The lower bulk density $\left(\rho_{b}\right)$ value for unirrigated land use can be attributed to high soil organic matter content, high sand content, high total porosity and less disturbance of the land under unirrigated land. Compaction of soil surface caused by intensive field traffic and deforestation also increases the soil bulk density $\left(\rho_{b}\right)$ in the irrigated land use. Soils having low and high bulk density $\left(\rho_{b}\right)$ respectively exhibit favorable and poor soil physical conditions (Hajabbasi et al., 1997; Patil and Jagdish, 2004). The highest bulk density $\left(\rho_{b}\right)$ in the irrigated land can be attributed to the soil compaction and soil organic matter degradation as a result of continuous and intensive irrigation with heavy farm machinery. The highest bulk density $\left(\rho_{b}\right)$ noted under the irrigated land could limit root growth, gas exchange and availability of less mobile plant nutrients (Dolan et al., 1992). Vertisols retained very high AWHC (>20\%), while Luvisols retained moderate to high (7-10.9\%). Thus, Vertisols is less susceptible to sealing of the surface pores during the rains and irrigation as compared to Luvisols. Therefore, Vertisols not only store more plant available water, but also allows more water entry to the soil reducing surface runoff. The reason for the lowest soil physical properties, such as bulk density $\left(\rho_{b}\right)$ on top soil surface for the two land use could be due to the low clay content, AWHC and

\section{Sci. Technol. Arts Res. J., Jan-March 2016, 5(1): 16-26}

high sand content, pore spaces and soil organic matter content (Table 1$)$. The bulk density $\left(\rho_{b}\right)$ increased with soil depth for all land use system. Similar results were reported by Yihenew and Getachew (2013).

Results of laboratory analyses for particle density ( $\rho s)$ of the studied soils showed significant variability with respect to land use and soil depth $(P<0.01)$, (Table 1$)$. However, particle density ( $\rho s)$ did not show any significant variation with soil type $(P>0.05)$. The highest particle density ( $\rho s$ ) of $2.79 \mathrm{~g} \mathrm{~cm}^{-3}$ was recorded at sub surface soil layer $(60-90 \mathrm{~cm})$ in irrigated land use. In unirrigated land, the finer soil particles will be selectively removed by erosion, thereby increasing the proportion of the total porosity in the soil which leaves more sand particles (Ayoubi et al., 2011) that increases particle density ( $\rho s)$. In similar soil types, keeping other things constant, soils with higher proportion of sand particles have higher particle densities ( $\rho s)$ than soils with high clay proportion.

The particle density ( $\rho$ ) increased with depth at (6090) for irrigated land use system, which could be due to the reduction of soil organic matter and increase in clay content. The particle density ( $\rho s)$ under the different land uses increased with increasing soil depth (Table 1), which was in harmony to the findings reported by Ahmed (2002). These higher particle density ( $\rho s)$ values on the subsurface soil layers might be due to the presence of heavy minerals of $\mathrm{Fe}$ and $\mathrm{Mn}$ in the sub surface soil (Wakene and Heluf, 2001).

The particle density increased with soil depth for all land use system. Similar results were reported by Yihenew and Getachew (2013). Results of laboratory analyses for total porosity of the studied soils showed significant variability with respect to soil depth $(p<0.01)$. The highest and the lowest total porosity observed in the irrigated (vertisols) land use were 53 and 46\%, respectively, (Table 1). An increase in total porosity in the soils of irrigated land use as compared to unirrigated land use attributed to a reduction in pore size distribution and sand content, increase in clay content and bulk density $\left(\rho_{b}\right)$. It is also closely related to the magnitude of soil organic matter loss which depends on the intensity of soil management practices. For instance, soil of irrigated land is highly subjected to soil compaction and subsequently decreased total porosity than soils of un-irrigated land. Higher bulk density $\left(\rho_{b}\right)$ and a concomitant lower total porosity due to change in land use also reported by (Celik, 2005) which is in agreement with the results of the present study.

Intensive cultivation (irrigation) without appropriate soil management might result in soil organic matter degradation. The decreased total porosity value with soil depth under un-irrigated land use attributed to accumulation of soil organic matter in top soil. This is apparently due to increasing $\rho_{b}$ and clay content with depth. The results obtained from this study are in agreement with the findings reported by other researchers (Teklu et al., 2004; Yihenew and Getachew, 2013). The total porosity values of the soil samples were in the range of values that adversely affect soil properties and, hence, root growth. The ranges of total porosity to affect soil properties and root growth depends on texture, sands with a total porosity space less than about $40 \%$ were able to restrict root growth due to excessive strength. Whilst, in clay soils, total porosity less than $50 \%$ were able to 
Getahun Kitila et al.,

restrict root growth. Unlike soil bulk density $(\rho b)$, total porosity was significantly $(P<0.05)$ but inversely associated with the silt fraction of the soils in the study area (Table 1).

Similarly, the Water content at permanent wilting point (PWP) was found to be significantly affected by soil type and soil depth $(P<0.01)$. However, PWP did not show any significant variation with land use $(P>0.05)$, (Table 1$)$. The variation in water content at FC with respect to land use, soil type and soil depth was statistically significant $(P<$ 0.05). In line with this, (Oriola, 2004) reported that the water content of the soil at different matric potentials depends on the soil organic matter content of the soil. Considering the main effects of land use, the highest $(40 \%)$ and lowest (22\%) water content at FC were found in the subsurface soil layer of unirrigated (Vertisols) land and unirrigated (Luvisols) land, respectively. The available water holding capacity (AWHC) was found to be significantly $(P<0.01)$ affected by land use, soil type, soil depth and the interaction effect. The highest (19\%) and lowest (13\%) water content at PWP were recorded in the irrigated (Luvisols) and Vertisols) land use, respectively. Accordingly, the highest AWHC of $22 \%$ among the land use types was obtained in the un-irrigated (vertisols) land and the lowest (8\%) in the un-irrigated (Luvisols) land use. This might have resulted from the low bulk density $\left(\rho_{b}\right)$, relatively higher clay content as well as from high soil organic matter content that are caused by microclimate differences induced by litter. Soil water content was the highest at the surface layer of the irrigated (Vertisols) land use system but the lowest for the un-irrigated (Luvisols) land use (Table 1). Moreover, the lowest FC in the Cultivation (irrigation) deteriorates soil structural
Sci. Technol. Arts Res. J., Jan-March 2016, 5(1): 16-26

aggregation reducing the soil water retention capacity (Wakene and Heluf, 2001).

The AWHC was the highest in unirrigated land use system. The mean value of AWHC for unirrigated Vertisols at surface soil layer $(0-30 \mathrm{~cm})$ was $18.86 \%$ and10.92 \% for unirrigated Luvisols in both soil sampling depth and sites. Higher clay content and soil organic matter provided large surface area required for absorption and retention of water molecules (Materechera and Mkhabela, 2001). Un-irrigated land use system has more AWHC compared to the irrigated land use (Ayoubi et al., 2011). It is apparent, however, that soils with clayey content have high moisture retention at FC and at PWP making the available water to crops to be lower than loam textured soils.

The variation in water content both at FC and PWP may be due to differences in their sand, silt and clay content (Table 1). The lower FC, PWP and AWHC in irrigated land use system was due to lower moisture contents which reduces AWHC of irrigated land use system through its adverse effects on both FC and PWP; however, the higher values of FC, PWP and AWHC of the irrigated land use system may be due to its higher clay content. This is in agreement with the finding of (Emerson, 1995) who concluded that increase in clay content increased both the FC and the PWP. Changes in soil water content and its possible effect on AWHC, FC and PWP indicated that, the soil water retention properties of the study area has been disturbed by changes in land use. This could be attributable to the variations in soil organic matter and clay contents with the land use system.

Table 1: Soil Physical properties under the different land use systems and soil depth and soil type

\begin{tabular}{|c|c|c|c|c|c|c|c|c|c|c|c|}
\hline \multirow{2}{*}{$\begin{array}{c}\text { Soil } \\
\text { Type }\end{array}$} & \multirow{2}{*}{$\begin{array}{l}\text { Depth } \\
\text { (cm) }\end{array}$} & \multicolumn{3}{|c|}{ Particle size (\%) } & \multirow{2}{*}{$\begin{array}{c}\text { Textural } \\
\text { class }\end{array}$} & \multirow{2}{*}{\multicolumn{2}{|c|}{$\rho_{\mathrm{b}} \mathrm{g} \mathrm{cm}^{-3}$}} & \multirow{2}{*}{$\begin{array}{l}\text { TP } \\
\text { (\%) }\end{array}$} & \multicolumn{3}{|c|}{ Moisture content (\%) } \\
\hline & & Sand & Silit & Clay & & & & & FC & PWP & AWHC \\
\hline \multicolumn{12}{|c|}{ Land Use (Unirrigated) } \\
\hline \multirow{3}{*}{ Luvisols } & $0-30$ & 40 & 12 & 47.3 & Sandy clay & 1.24 & 2.64 & $48.40^{f}$ & $24.67^{a}$ & $13.75^{\mathrm{a}}$ & $10.92^{d}$ \\
\hline & $30-60$ & 36 & 11 & 53.3 & Sandy clay & 1.29 & 2.41 & $47.86^{\mathrm{h}}$ & $21.37^{\mathrm{b}}$ & $13.88^{\mathrm{a}}$ & $7.48^{\mathrm{e}}$ \\
\hline & $60-90$ & 36 & 11 & 53.0 & Sandy clay & 1.25 & 2.31 & $46.99^{j}$ & $22.34^{\mathrm{b}}$ & $13.95^{\mathrm{a}}$ & $8.38^{\mathrm{e}}$ \\
\hline \multirow{3}{*}{ Vertisols } & $0-30$ & 25 & 11 & 64.0 & Clay & 1.26 & 2.59 & $48.80 d$ & $37.20^{c}$ & $18.43^{b}$ & $18.86^{c}$ \\
\hline & $30-60$ & 26 & 9 & 64.2 & Clay & 1.28 & 2.59 & $48.04^{\mathrm{g}}$ & $39.82^{c}$ & $18.27^{\mathrm{b}}$ & $21.54^{\mathrm{a}}$ \\
\hline & $60-90$ & 24 & 11 & 65.3 & Clay & 1.27 & 2.61 & $47.47^{i}$ & $39.98^{c}$ & $18.14^{\mathrm{c}}$ & $21.83^{\mathrm{a}}$ \\
\hline \multicolumn{12}{|c|}{ Land Use (Irrigated) } \\
\hline \multirow{3}{*}{ Luvisols } & $0-30$ & 30 & 12 & 58.0 & Clay & 1.32 & 2.59 & $49.96^{a}$ & $20.59^{\mathrm{e}}$ & $12.69^{b}$ & $7.90^{\mathrm{e}}$ \\
\hline & $30-60$ & 29 & 11 & 60.3 & Clay & 1.36 & 2.70 & $49.37^{b}$ & $22.67^{d}$ & $14.51^{b}$ & $8.15^{\mathrm{e}}$ \\
\hline & $60-90$ & 28 & 11 & 61.0 & Clay & 1.38 & 2.79 & $48.18^{c}$ & $24.36^{d}$ & $14.27^{b}$ & $10.08^{d}$ \\
\hline \multirow{3}{*}{ Vertisols } & $0-30$ & 24 & 10 & 65.4 & Clay & 1.32 & 2.62 & $53.38^{b}$ & $35.35^{c}$ & $17.70^{b}$ & $17.64^{c}$ \\
\hline & $30-60$ & 25 & 10 & 64.3 & Clay & 1.34 & 2.69 & $48.81^{d}$ & $38.18^{a}$ & $18.44^{b}$ & $19.74^{b}$ \\
\hline & $60-90$ & 23 & 11 & 66.0 & Clay & 1.39 & 2.78 & $46.13^{\mathrm{e}}$ & $38.70^{c}$ & $18.48^{b}$ & $20.16^{\mathrm{b}}$ \\
\hline
\end{tabular}

Overall means within rows and columns followed by different letters are significantly different $(P<0.05)$ with land use and soil depth. Separation when the analysis of variance showed statistically significant differences $(P<0.05)$. $\mathrm{pb}=$ Bulk density, $\rho \mathrm{s}=$ Particle density, TP = Total porosity, $\mathrm{FC}=$ field capacity, $\mathrm{PWP}=$ permanent wilting point, AWHC = available water holding capacity

The saturated hydraulic conductivity (Ksat) varied from 0.68 to $4.71 \mu \mathrm{m} \mathrm{s}^{-1}$ for Luvisols and 0.24 to $4.85 \mu \mathrm{m} \mathrm{s}^{-1}$ for Vertisols. The highest Ksat at the surface soil layer (depth) must have been caused by increased total porosity in soil or tillage. Previous researches indicated that Ksat can be greater for tilled than untilled soil. The general decline in Ksat with soil depth could be the result of decrease in the proportion of macro pores in the lower soil depth. As a result, high Ksat was recorded in the saturated Luvisols soils than the Vertisols soils. In waterlogged areas of the irrigated sugarcane plantation of FVSE soils where Vertisols are found, shallow water table accompanied with low Ksat were already identified giving some indications of drainage needs. On the basis of Ksat ratings established by (Guildhall and Tripathi, 1987), the two major soils can be categorized in to slow to moderately slow. 


\section{Getahun Kitila et al.,}

These results suggested that when frequently irrigated, the Vertisols may generate extremely high runoff and deep drainage losses hence very good prospects of harvesting runoff water. This is because under extremely wet soil conditions, the internal profile drainage of the Vertisols is poor due to very low Ksat of different soil layers. High runoff on both soils results in serious soil erosion and water logging problems. The basic infiltration rate, alike the Ksat values, showed a decreasing trend with both soil types with increased in soil depth down the profile.

\section{Selected Soil Chemical Properties under Different Land use in the Study Area}

The analytical data of selected soil chemical properties under irrigated and un-irrigated land use of dominant soil types (Luvisols and Vertisols) are presented in table 2. The analysis of variance revealed that soil $\mathrm{pH}$ was significantly $(P<0.01)$ affected by soil type and the interaction. The highest soil $\mathrm{pH}$ values of 6.80 and 5.95 in surface soil layer were found under the un-irrigated (Luvisols and Vertisols) land; whereas, the lowest soil $\mathrm{pH}$ values of 6.20 and 6.26 were registered under the irrigated (Luvisols and Vertisols) land, respectively (Table 2). The higher soil $\mathrm{pH}$ in the lower soil layer than in the top soil layer (Table 2) might be due to the presence of relatively higher soil OM in the top surface soil. This result was in agreement with the finding of (Hajabasi et al., 2007; Asadi et al., 2010; Tadele et al., 2013) who found a non-significant difference in soil $\mathrm{pH}$ between soils on conserved dry farm land and degraded rangeland of semiarid region of Iran, Soil Properties and Crop yields along the terraces and toposequence in the Anjeni Watershed, Central Highland of Ethiopia. Mulugeta and Stahr (2010) also indicated that tropical soils are deficient in soil $\mathrm{pH}$. Soil $\mathrm{pH}$ could also be associated with the type of parent material and extent of soil erosion. Therefore, the relatively lower soil $\mathrm{pH}$ value for the surface top soil layer could be attributed to the relatively lower soil organic matter content while the highest soil $\mathrm{pH}$ value in the sub surface layer could be attributed to the presence of higher exchangeable cations due to reduced erosion.

The overall soil $\mathrm{pH}$ rating of the studied soils revealed that the soils are found to be moderately acidic. Unirrigated Vertisols were more acidic, owing to more uptakes of basic cations by the irrigation and high AWHC. The relative decline in soil $\mathrm{pH}$ at the surface soil of unirrigated land could be also due to oblong shaped canopy leading the rain to form big drops consequently enhancing leaching of basic cations as well by releasing organic acids associated with mineralization of soil organic matter content (Mohammed et al., 2005). This pattern of variability in soil $\mathrm{pH}$ could be associated with the increase in depth that could be attributed to the downward movement of solutes by leaching within a profile (Mohammed et al., 2005). Malo et al. (2005) also reported, the increase in soil $\mathrm{pH}$ with soil depth could be associated with enhanced carbonate levels and less weathering rates.

Electrical conductivity (EC) of soils was significantly $(P<0.01)$ affected by land use, soil type and soil depth (Table 2). The highest $\left(210 \mu \mathrm{S} \mathrm{cm}{ }^{-1}\right)$ but $\left(50 \mu \mathrm{sm}^{-1}\right)$ occurs also in un irrigated Vertisols. The highest $E C$ value under the un irrigated (Luvisols) land might be due to its highest exchangeable $\mathrm{Na}$ content, whereas the lowest soil EC value under the irrigated (Vertisols) land can be
Sci. Technol. Arts Res. J., Jan-March 2016, 5(1): 16-26

associated with the loss of cations $\left(\mathrm{Ca}^{2+}\right.$ and $\left.\mathrm{Mg}^{2+}\right)$ after deforestation and intensive cultivation. As indicated in Table 2, relatively, higher EC values were recorded in the surface than in the subsurface soils. The mean EC values of the land use and soil types by subsoil layer treatment combinations were significantly different $(P<0.01)$ from each other (Table 2). Considering the land use and soil depth, the highest value of EC $\left(210 \mu \mathrm{S} \mathrm{cm}^{-11}\right)$ was obtained in the surface soil layer $(0-30 \mathrm{~cm})$ layer of the un irrigated (Luvisols) land. The EC reduced gradually with depth. This low salt concentration and low variation with depth indicated that salts in these fields were leached uniformly throughout the soil profile by frequent irrigations that applied water in excess of crop requirement. This ensured an environment that sustained sugarcane production in the scheme during most months of the year.

The study also revealed that the available $P$ in the soil varied significantly $(P<0.05)$ with soil depth. The overall available $P$ was not statistically significant $(P>0.05)$ with land use and soil type (Table 2). The higher available $P$ in the top soil layer was (19.35 and $\left.17.93 \mathrm{mg} \mathrm{kg}^{-1}\right)$, respectively for irrigated (Luvisols) and irrigated (Vertisols) land use type (Table 2), which may be related to the application of Diammonium phosphate (DAP) fertilizer for soil fertility improvement. Yimer et al. (2006) also reported similar results. The overall available $\mathrm{P}$ was lower in the lower soil layer.

It is apparent that with higher available $\mathrm{P}$ concentration in the top layer there will be relatively higher biomass production and in turn produces higher soil organic matter which is the store of $P$. According to Landon (1991) rating available $P$ across the land use was low except in the top soil layer of irrigated land. The available $P$ deficiency in soils of the study area may be due to the inherent low-P status. Other studies (Sintayehu, 2006; Wakene and Heluf, 2003) also reported that the available $P$ in most soils of Ethiopia is lowdue to $P$ - fixation, crop harvest, and erosion by water.

The study also revealed that the calcium carbonate $\left(\mathrm{CaCO}_{3}\right)$ content varied significantly $(P<0.05)$ with land and soil depth. The values of $\mathrm{CaCO}_{3}$ for the soil in the study site varied from 1.97 to 2.87 and 1.44 to $1.47 \mathrm{mg} / \mathrm{kg}$ for unirrigated Luvisols and Vertisols, respectively and 1.82 to 1.83 and 1.87 to 2.10 for irrigated Luvisols and Vertisols, respectively. The highest value of soil $\mathrm{CaCO}_{3}$ was 2.87 for un irrigated Luvisols. This can be due to in appropriate management practices including tillage or severe soil erosion that cause the underlying soil containing more soil $\mathrm{CaCO}_{3}$, to move to the surface. However, the high $\mathrm{CaCO} 3$ contents in the irrigated Vertisols may be attributed to the clay content proportion of the soil layer (Reid and Dirou, 2004).

The overall soil organic matter content with land use type, soil depth and soil type was not statistically significant $(P>0.05)$. Though not significant, the soil organic matter showed a general decreasing trend. The depletion of soil organic matter was higher in irrigated land than unirrigated land. This is attributed with the fact that, cultivation increases soil aeration which enhances decompositions of soil organic matter and most of the percent soil organic matter produced in soils of cultivated land are removed with harvest causing for its reduction in values of soil organic matter content which in turn an increased soil bulk density $(\rho b)$ and decreased soil total 


\section{Getahun Kitila et al.,}

porosity Across soil depth soil organic matter content was higher in the top soil layer than in the lower layer. In the top soil layer soil organic matter content was higher in unirrigated land than in irrigated land use type (Table 2).

The higher overall soil organic matter content in the unirrigated land than in irrigated for Vretisols may also be attributed to the higher accumulation of soil organic matter due to high inputs from root biomass and above ground biomass. This is in line with the findings of (Hajabasi et al., 2009; Khormali et al., 2009; Yimer et al., 2006).The lower soil organic matter content under irrigated land than in unirrigated land use system could be due to the reduced amount soil organic matter being returned to the soil system and high rate of oxidation of soil organic matter as a result of continuous irrigation for long period of time without fallowing, loss of soil organic matter by water erosion, and removal of green materials (Yimer et al., 2006; Girmay et al., 2008). Irrigation promotes soil
Sci. Technol. Arts Res. J., Jan-March 2016, 5(1): 16-26

organic matter loss due to exposure of micro-aggregate soil organic matter to microbial decomposition by changing the moisture and temperature regimes (Reicosky et al., 1998). As per the rating of nutrients suggested by (Tekalign, 1991) for Ethiopian soils soil organic matter content was found to be very low in all land uses (Table 2), indicating that soils of the study area were threatened by the continuous human interference, mechanical effect of heavy machines use and intensive agricultural production systems. Results of laboratory analyses for total $\mathrm{N}$ content and $\mathrm{C}$ : $\mathrm{N}$ of soil under different land use system are shown in Table 2.The difference in total $\mathrm{N}$ was not statistically significant with land use, Soil type,soil depth and the interaction effect $(P>0.05)$. However, the distribution of total $\mathrm{N}$ content followed a similar pattern to soil organic matter distribution and was relatively higher in the in irrigated land at the subsurface layer $(30-60 \mathrm{~cm})$. Such result is expected since most soil total $\mathrm{N}$ is bound in soil organic matter.

Table 2: Mean values of $\mathrm{pH}, \mathrm{EC}, \mathrm{CaCO} 3, \mathrm{Av} . \mathrm{P}, \mathrm{OM}, \mathrm{TN}$, and $\mathrm{C}: \mathrm{N}$ in relation to land use, soil type and soil depth (cm)

\begin{tabular}{|c|c|c|c|c|c|c|c|c|}
\hline $\begin{array}{l}\text { Soil } \\
\text { Type }\end{array}$ & $\begin{array}{c}\text { depth } \\
\text { (cm) }\end{array}$ & $\mathrm{pH}$ & $\begin{array}{c}E C \\
\left(\mu \mathrm{S} \mathrm{cm}^{-11}\right)\end{array}$ & $\begin{array}{c}\mathrm{Ca} \mathrm{CO}{ }_{3} \\
\left(\mathrm{mg} \mathrm{kg}^{-1}\right)\end{array}$ & $\begin{array}{c}\text { Available P } \\
\left(\mathrm{mg} \mathrm{kg}^{-1}\right)\end{array}$ & $\begin{array}{c}\text { Soil OM } \\
(\%)\end{array}$ & $\begin{array}{r}\begin{array}{c}\text { Total N } \\
(\%)\end{array} \\
\end{array}$ & C: $\mathbf{N}$ \\
\hline \multicolumn{9}{|c|}{ Land use (Un-irrigated) } \\
\hline \multirow{3}{*}{ UL } & $0-30$ & $6.3( \pm 0.28)^{a b c d}$ & $210( \pm 0.02)^{\mathrm{a}}$ & $1.97( \pm 0.50)^{b}$ & $19.13( \pm 11.0)^{\mathrm{a}}$ & $2.12( \pm 0.2)^{\mathrm{a}}$ & $0.123( \pm 0.011)^{\mathrm{a}}$ & $10( \pm 0.15)$ \\
\hline & $30-60$ & $6.5( \pm 0.28)^{\mathrm{abc}}$ & $110( \pm 0.02)^{\mathrm{b}}$ & $2.87( \pm 0.50)^{\mathrm{a}}$ & $8.12( \pm 11.0)^{\mathrm{e}}$ & $1.99\left( \pm 0.2^{\mathrm{ja}}\right.$ & $0.120( \pm 0.011)^{\mathrm{a}}$ & $9.7( \pm 0.15)$ \\
\hline & $60-90$ & $6.8( \pm 0.28)^{\mathrm{a}}$ & $100( \pm 0.02)^{b}$ & $1.87( \pm 0.50)^{b}$ & $6.26( \pm 11.00) \mathrm{g}$ & $1.76( \pm 0.2)^{a}$ & $0.123( \pm 0.011)^{\mathrm{a}}$ & $8.3( \pm 0.15)$ \\
\hline \multirow{3}{*}{ UV } & $0-30$ & $6.0( \pm 0.16)^{\mathrm{bcd}}$ & $90( \pm 0.02)^{b}$ & $1.47( \pm 0.29)^{b}$ & $14.23( \pm 6.3)^{\mathrm{C}}$ & $2.12( \pm 0.2)^{\mathrm{a}}$ & $0.121( \pm 0.006)^{\mathrm{a}}$ & $10.2( \pm 0.02)$ \\
\hline & $30-60$ & $5.8( \pm 0.16)^{c d}$ & $80( \pm 0.02)^{b}$ & $1.19( \pm 0.29)^{\mathrm{c}}$ & $4.12( \pm 6.3)^{i}$ & $2.05( \pm 0.2)^{a}$ & $0.113(+0.006)^{a}$ & $9.2( \pm 0.02)$ \\
\hline & $60-90$ & $5.9( \pm 0.16)^{d}$ & $60( \pm 0.02)^{\mathrm{b}}$ & $1.44( \pm 0.29)^{\mathrm{b}}$ & $3.45( \pm 6.3)^{j}$ & $1.80( \pm 0.2)^{\mathrm{a}}$ & $0.113( \pm 0.006)^{\mathrm{a}}$ & $10.5( \pm 0.02)$ \\
\hline \multicolumn{9}{|c|}{ Land use (Irrigated) } \\
\hline \multirow{3}{*}{ IL } & $0-30$ & $6.2( \pm 0.11)^{\mathrm{bcd}}$ & $90( \pm 0.01)^{b}$ & $1.83(+0.21)^{\mathrm{b}}$ & $19.35(+4.5)^{\mathrm{a}}$ & $2.14( \pm 0.08)^{\mathrm{a}}$ & $0.123( \pm 0.004)^{\mathrm{a}}$ & $10(+0.12)$ \\
\hline & $30-60$ & $6.2( \pm 0.11)^{\mathrm{bcd}}$ & $80( \pm 0.01)^{b}$ & $1.89( \pm 0.21)^{b}$ & $11.71( \pm 4.5)^{d}$ & $2.12( \pm 0.08)^{a}$ & $0.125( \pm 0.004)^{\mathrm{a}}$ & $10( \pm 0.12)$ \\
\hline & $60-90$ & $6.2( \pm 0.11)^{\mathrm{bcd}}$ & $90( \pm 0.11)^{\mathrm{b}}$ & $1.82( \pm 0.21)^{b}$ & $5.10( \pm 4.5)^{n}$ & $2.06( \pm 0.08)^{a}$ & $0.116( \pm 0.004)^{\mathrm{a}}$ & $9.9(+0.12)$ \\
\hline \multirow{3}{*}{ IV } & $0-30$ & $6.3( \pm 0.09)^{\mathrm{abc}}$ & $80( \pm 0.01)^{b}$ & $1.87( \pm 0.16)^{b}$ & $17.93( \pm 3.6)^{b}$ & $2.03( \pm 0.06)^{\mathrm{a}}$ & $0.125(+0.003)^{\mathrm{a}}$ & $9.0( \pm 0.06)$ \\
\hline & $30-60$ & $6.3( \pm 0.09)^{a b c}$ & $70( \pm 0.01)^{\mathrm{b}}$ & $1.73( \pm 0.16)^{b}$ & $6.26( \pm 3.6)^{g}$ & $1.99( \pm 0.06)^{\mathrm{a}}$ & $0.114( \pm 0.003)^{\mathrm{a}}$ & $10( \pm 0.06)$ \\
\hline & $60-90$ & $6.5( \pm 0.09)^{\mathrm{abc}}$ & $50( \pm 0.01)^{b}$ & $2.10( \pm 0.16)^{b}$ & $7.44( \pm 3.6)^{f}$ & $1.95(+0.06)^{\mathrm{a}}$ & $0.112(+0.003)^{\mathrm{a}}$ & $10(+0.06)$ \\
\hline
\end{tabular}

Though not statistically significant, the relatively higher total $\mathrm{N}$ in the un irrigated land than in the irrigated land could be associated with the relatively higher soil organic matter which in turn resulted from plant and root biomass as well as residues being returned to the soil system. The principal cause for lower contents of total $\mathrm{N}$ comes from biomass removal during crop harvest and insufficient replenishment through fertilizers. The difference between the surface and subsurface soil layer for total $\mathrm{N}$ was not statistically significant $(P>0.05)$ and the highest content was found from the irrigated (Luvisols) sub surface soil layer (Table 2). The total $\mathrm{N}$ content for sub surface soil layer is rated as medium while surface soil layers of the irrigated plots rated low according to the rating by Landon (1991). Siriri et al. (2005) also noted lower total N values on the upper layers and moderately increased on the lower layers.

Million (2003) and Tadele et al. (2013) also found that the total $\mathrm{N}$ content of the terraced site compared to their corresponding non-terraced sloping areas. The decline in soil organic matter and total $\mathrm{N}$ due to land use change concurs with the findings of (Jaiyeoba, 2003; Heluf and Wakene, 2006; Abbasi et al., 2007). Exposure of the top soil to rainfall and irrigation water brings about erosion, rapid decomposition of soil organic matter and intense leaching of basic nutrients rendering the soil infertile and the agricultural production unsustainable. This is obvious as the contents of total $\mathrm{N}$ in the soil area function of the amount of soil organic matter and vice versa. Peaceful Valley Farm Supply (Technical Booklet, 2004) noted that the higher the soil organic matter content, the higher the potential $\mathrm{N}$ released in the soil. In addition, it implies that both are influenced by the accumulation of biomass in the soil layer. Numerically, distribution of $\mathrm{C}$ : $\mathrm{N}$ followed similar patterns to soil organic matter and total $\mathrm{N}$ distributions except slight variation within the land uses. Relative to unirrigated land use, the irrigated (Vertisols) land recorded narrow $\mathrm{C}$ : $\mathrm{N}$ at the surface layer. Aeration during tillage and increased temperature that enhance mineralization rates of soil organic matter than organic nitrogen could probably be the causes for the lower level of $\mathrm{C}$ : $\mathrm{N}$ in irrigated land. The narrow $\mathrm{C}$ : $\mathrm{N}$ in soil of irrigated land concurs with the study of (Abbasi et al., 2007) who concluded higher microbial activity and more $\mathrm{CO}_{2}$ evolution and its loss to the atmosphere in the top (0-30 $\mathrm{cm})$ soil layer resulted to the narrow $\mathrm{C}$ : $\mathrm{N}$. The $\mathrm{C}$ : $\mathrm{N}$ an index of nutrient mineralization and immobilization whereby low $\mathrm{C}$ : $\mathrm{N}$ indicated higher rate of mineralization. The C: $\mathrm{N}$ ofthe studied soil did not show any significant variation with land use types, soil type and soil depth, $(p>$ $0.05)$, (Table 2). Yet, the numerical values for land uses 


\section{Getahun Kitila et al.,}

were highest for irrigated soils and lowest for unirrigated soils which can be due to the rapid loss of nitrogen (the denominator) in the former

Thus, one can understand that the impact of land use and associated management was more pronounced in total $\mathrm{N}$ than soil organic matter. Similarly, Khresat et al. (2008) and Nega and Heluf (2013) reported that C: N did not show a significant variation with land uses. The overall $\mathrm{C}$ : $\mathrm{N}$ was higher in the top surface soil layer than in the layer below. In the study area, the $\mathrm{C}$ : $\mathrm{N}$ was found to be higher (Table 2) than the normal range 10:1 on average (Landon, 1991) expected in mineral soils. However, Tadele et al. (2012) reported higher C:N indicating that nitrogen is immobilized at higher $\mathrm{C}: \mathrm{N}$ values because of the formation of only slightly biodegradable complexes which are low in total $\mathrm{N}$ content of the parent material and erosion loss. This implies that increase in soil organic matter content significantly increased the C:N.

\section{CONCLUSIONS}

Variations in soil quality indicators with respect to land use, soil type and soil depth were investigated in the study area. Particle size distribution varied with land use, while silt, clay, and bulk density ( $\rho b)$ differed with soil depth. There was a significant difference for bulk density, particle size distribution, and clay content and soil $\mathrm{pH}$ among the two land uses. In general, the continuous intensive cultivation and mismanagement of land, irrigation water as well as misuse of fertilizers for sugarcane crop production without appropriate soil management has degraded most of the important soil quality indicators. This consequently led to loss of available nutrient for plant production as well as to global warming by affecting soil reserve of carbon as a result of burning of cane residue. Such practices may also disturb soil structure and result in variations and even deterioration of soil quality attributes among land use types of same soil type (Luvisols and Vertisols). Therefore, reducing intensive cultivation, and integrated use of inorganic and organic fertilizers could replenish the degraded soil quality parameters for sustainable agricultural production and productivity in the study area.

\section{Acknowledgments}

The authors are grateful for Ethiopian Water Design and Supervision for its facilitation to use soil laboratory facilities. They also acknowledge Fincha'a Valley Sugar Estate for its unbounded service and cooperation during the field work and facilitation to use soil laboratory facilities. Mr. Zewdie Wondiatir and Diriba Shifarew are also gratefully acknowledged for their unreserved assistance.

\section{REFERENCES}

Abbasi, M.K., Zafar, M. and Khan, S.R. (2007). Influence of different land-cover types on the changes of selected soil properties in the mountain region of Rawalakot Azad Jammu and Kashmir. Journal of Nutrient Cycling in Agroecosystems 78: 97-110.

Achalu Chimdi., Heluf Gebrekidan., Kibebew Kibret and Abi Tadesse. (2012). Status of selected physicochemical properties of soils under different land use systems of Western Oromia, Ethiopia. Journal of Biodiversity and Environmental Sciences 2(3): 57-71.

Ademe Adenew. (2001). Summary of Metrological Data (1979-2000), Fincha'a Research Station, Agriculture, Ethiopia. 272pp.
Sci. Technol. Arts Res. J., Jan-March 2016, 5(1): 16-26

Ahmed Amdihun (2007). GIS and remote sensing integrated environmental impact assessment of irrigationproject in Fincha'a Valley area, Ethiopia. Journal of Catchment and Lake Research 3(2):118-128.

Ahmed Hansen (2002). Assessment of Special Variability of Some Physicochemical Property of Soil under Different Elevation and Land Use systems in the Western slopes of Mount Chilalo, Arisi. MSc Thesis, Alemaya University, Ethiopia.

Ambachew Damite and Girma Abejehu (2005). Review of sugar cane research in Ethiopia: I. Soil irrigation and mechanization (1964-1998), RTSD, ESISCSh.Co. Wonji.

APHA (American Public Health Association) (2005).Standard methods for examination of water and wastewater.21 ${ }^{\text {th }}$ ed. American Public Health Association, Washington, DC, USA.

Asadi, H., Raeisvandi, A., Rabiei, B., AND Ghadiri, H. (2011). Effect of land use and topography on soil properties and agronomic productivity on calcareous soils of a semi-arid region, Iran. Land degradation and Development 1-9.

Awdenegest, M., Melku D. and Fantaw Y. (2013). Land Use Effects on Soil Quality Indicators: A Case Study of AboWonsho Southern Ethiopia. Journal of Applied and Environmental Soil Science 4(3):1-10.

Baruah, T. and Barthakur, H. (1998). A Textbook of Soil Analysis.Vikas publishing House Pvt. Ltd., New Delhi, India.

Bezuayehu Tefera. (2008). Hydropower-Induced Land Use Change in Fincha'a Watershed, Western Ethiopia: Analysis and Impacts. Journal of Mountain Research and Development 28(1):72-80.

Blake, G.R. and Hartge, K.H. (1986). Particle density. In: Klute, A. (Ed.), Methods of Soil Analysis. Part 1.Physical and Mineralogical Methods. American Society of Agronomy., Madison, I, pp. 377-382.

Chatsworth, W. (2008). Encyclopedia of Soil Science, Springer, Dordrecht, the Netherland.

Celik I. (2005). Land use effects on organic matter and physical properties of soil in southern Mediterranean highland of Turkey. Journal of Soil and Tillage Research 83: $270-277$.

Day, P.R. (1965). Hydrometer method of particle size analysis. pp. 562-563. In: C.A. Black (Ed.). Methods of Soil Analysis. Agronomy Part I, No. 9. American Society of Agronomy, Madison, Wisconsin, USA.

Dereje Gutema (1993). Phosphorus status and availability to Sugarcane (Saccharum officinarum L.) Grown on two major soil types in Fincha'a valley: MSc Thesis. Alemaya University, Ethiopia.

Dolan, M.S., Dowdy, R.H. Voorhees, W.B., Johnson, J.F. and Bidwell Schrader, A.M. (1992). Corn P and potassium uptake in response to soil compaction. Agronomy Journal 84: 639-642.

Dexter, A.R. (2004). Soil physical quality Part I. Theory, effects of soil texture, density, and organic matter, and effects on root growth, Geoderma 120(3-4): 201-214.

Ebtisam, I., Dardiry, E.I. (2007). Soil available water as affected by some soil physicochemical properties. Australian Journal of Soil Research 33: 241-251.

Emerson, W.W. (1995). Water retention, organic carbon and soil texture. Australian Journal of Soil Research 33: 241251. 
Getahun Kitila et al.,

Eyasu, E. (2002). Farmers' Perceptions of Soil Fertility Change and Management.Doctoralthesis SOS SAHEL and Institute for Sustainable Development. Addis Ababa, Ethiopia. 252pp.

FAO (Food and Culitivated Organization), (1989). Water quality for agriculture. FAO, Rome, pp. 163.

Fekadu Getachew., Abdu Abdlkadir., Mulugeta Lemneh and Aramde Fetene (2012). Effects of different Land uses on soil physical and chemical properties in Wendo Gent Area, Ethiopia New Yourk. Journal of Science 5(11).

Garcia-Orenes, F., Cerd'a, A. and Mataix-Solera., J. (2009). Effects of culitivated management on surface soil properties and soil water losses in eastern Spain, Journal ofSoil and Tillage Research 106(1): 117-123.

Garcia-Orenes, F., Guerrero, C.and Rold'an, A. (2010). Soil microbial biomass and activity under different culitivated management systems in a semiarid Mediterranean agro ecosystem. Journal of Soil and Tillage Research 109(2): 110-115.

Garcia-Orenes, F., Rold'an, A. and Mataix-Solera, J. (2012). Soil structural stability and erosion rates influenced by culitivated management practices in a semi-arid Mediterranean agro ecosystem. Journal of Soil Use and Management 28(4): 571-579.

Gardner, W.H. (1986). Water content. In: Klute, A. (Ed.), Methods of Soil Analysis. Part I. Physical and Mineralogical Methods. $2^{\text {nd }}$ edition. American Society of Agronomy, Madison, I: 493-541.

Gebeyaw Tadesse (2006). Soil Fertility Status as Influenced by Different Land Uses in Maybar Areas of South Wello Zone, Ethiopia M.S. thesis,Haramaya University, Ethiopia.

Ghildyal, B.P. and Tripathi, R.P. (1987). Soil physics. Wiley Eastern Limited, Pantiager, U.P., India. 654p.

Girmay Gebregorgis., Singh, B. R., Mitiku Haile., Borresen, T. and Lal, R. (2008). Carbon stocks in Ethiopian soils in relation to land use and soil management, Journal of Land Degradation and Development 19(4): 351-367.

Hajabasi, M.A.., Besalatpoor, A. and Melali, A.R. (2007). Effect of rangeland change to 10.culitivated land on some soil physical and chemical properties in South of Isfahan. Journal of Agriculture and Natural Resources 42: 525-53.

Heluf Gebrekidan and Wakene Negassa (2006). Impact of land use and management practices on chemical properties of some soils of Bako area, Western Ethiopia. Ethiopian Journal of Natural Resources 8: 177-197.

Islam, K.R. and Weil, R.R. (2000). Land use effects on soil quality in a tropical natural forest ecosystem of Bangladesh. Journal of Agriculture, Ecosystems and Environment 79: 9-16.

Jaiyeoba, I.A. (2003). Changes in soil properties due to continuous cultivation in Nigerian semiarid savannah. Journal ofSoil and Tillage Research 70: 91-98.

Kebede Seifu (1998). Estimating Land Cover/Landuse Changes in Munessa Natural forest area using Remote Sensing Techniques. MSc. Thesis Report No. 1998:32, Swedish University of Culitivated Sciences, Skinnskatteberg.

Landon, J.R. (1991). Booker tropical soil manual: A Handbook for soil Survey and culitivated land evaluation in the tropics and subtropics. Longman Scientific and Academic Press, Inc. San Diego. 413.
Sci. Technol. Arts Res. J., Jan-March 2016, 5(1): 16-26

Karlen, D.L., Mausbach, M.J., Doran, J.W., Cline, R.G., Harris, R.F. and Schuman, G.E. (1997). Soil quality: a concept, definition, and framework for evaluation. Journal ofSoil Science Society of America 61(1): 4-10.

Khresat, J., Al-Bakri and Al-Tahnan, R. (2008). Impacts of land use/cover change on soil properties in the Mediterranean region of northwestern Jordan, Journal of Land Degradation and Development 19(4): 397-407.

Khormali, F., Ajami, M., Ayoubi, S., Srinivasarao, C. and Wani, S. (2009). Role of deforestation and hill slope position on soil quality attributes of loess-derived soils in Golestan province, Iran, Agriculture. Journal of Ecosystems and Environment 134(3-4): 178-189.

Klute, A., Dirksen, C. (1986). Hydraulic conductivity and diffusivity: Laboratory Models. In a Klute edition.Methods of Soil Analysis, part1, $2^{\text {nd }}$ edition, Agronomy. Monogr.687-734.

Majaliwa, J.G., Twongyirwe, R., Nyenje, R. Oluka, M., Ongom, B. Sirike, J., Mfitumukiza, D. Azanga, E..Natumanya, R., Mwerera, R. and Barasa, B. (2010). The Effect of Land Cover Change on Soil Properties around Kibale National Park in South Western Uganda. Journal of Applied and Environmental Soil Science 10: 17 .

Malo, D.D., Schumacher, T.E. and Doolittle, J. (2005). Longterm cultivation impacts on selected soil properties in the northern Great Plains. Journal of Soil and Tillage Research 81: 277-291.

Materechera, W.W. and Mkhabela, T. (2000). Influence of land-use on properties of a ferralitic soil under low external input farming in southern Swaziland. Journal ofSoil and Tillage Research 62: 15-25.

Million, A. (2003). Characterization of Indigenous Stone Bunding (Kab) and Its Effect on Crop Yield and Soil Productivity at Mesobit-Gedeba, North Showa Zone of Amhara Region.Master's thesis, Alemaya University, Ethiopia.

Moges, A. and Holden, M. (2008). Soil fertility in relation to slope position and culitivated land use: a case study of umbulo catchment in Southern Ethiopia, Journal of Environmental Management 42(5): 753-763.

Mehmood, K., Ahmed, S. and Khan, K. (2005). Maize growth as influenced by different manures in pothwar tract (Pakistan). International of Journal of Agriculture and Biology 7(3): 521- 523.

Mulugeta Lemneh (2004). Effects of Landuse Changes on Soil Quality and Native Flora Degradation and Restoration in the High Land of Ethiopia. Implication for food Security.Doctoral Thesis.Uppsala, Swedish university of culitivated science.

Mulugeta, D. and Stahr, K. (2010). Assessment of integrated soil and water conservation measures on key soil properties in south Gondar, north-western Highland of Ethiopia. Journal of Soil Science and Environmental Management 1(7): 164-176.

Nega Emiru and Heluf Gebrekidan (2013). Effect of Land Use Changes and Soil Depth on Soil Organic Matter, Total Nitrogen and Available Phosphorus Contents of Soils in Senbat Watershed, Western Ethiopia. ARPN Journal of Culitivated and Biological Science 8(3): 1990-6145.

Olsen, S.R., Cole, C.V., Watanabe, F.S. and Dean, L.A. (1954). Estimation of available $P$ in soils by extraction with sodium bicarbonate. USDA circular 939.1-19p. 
Getahun Kitila et al.,

Oriola, E.Q. (2004). Dynamics of soil chemical poperties in Oke-Oyi'Irrigation Projects sitc of the Lower Niger River basin development Aiitlrority, Ilorin. Nigeria"Geo'sttdies Forum. International Journal of Environment and policy Issue 2(1): 96-105.

Ozgoz, E., Gunal, H., Acir, N., Gokmen, F., Birol, M. and Budak, M. (2011). Soil quality and spatial variability assessment of land use effects in a typical haplustoll. Journal of Land Degradation and Development, 24(5):382-390.

Sahelemedin, S. and Taye, B. (2000). Procedures for Soil and Plant Analysis.Technical paper no. 74.National Soil Research Centre, Ethiopian Culitivated Research Organization, Addis Ababa, Ethiopia.

SAS (2004). SAS/STAT user's guide.Proprietary software ver 9.00. SAS Inst., Inc., Cary, NC.

Singh, M.J. and Khera, K.L. (2009). Physical indicators of soil quality in relation to soil erodibility under different land uses. Journal ofArid Land Research and Management, 123(2): 152-167.

Sintayehu, M. (2006). Land Use Dynamics and its Impact on SelectedPhysicochemical Properties of Soils in Yabello Woreda of BoranaLowland, Southern Ethiopia M.S. thesis, Haramaya University, Ethiopia,

Sirri, D., Tanya, M.M., Rousse, T. and Sake, J. K. (2005). Crop and soil variability on terraces in the Highland of SW Uganda. Journal of Land Degradation and Development 1: $569-579$

Tadele Amare., Aemro, T., Yihenew Gebresilase., Birru Yitaferu., Bettina, W. and Hans, H. (2013). Soil Properties and Crop Yields along the Terraces and Toposequence of Anjeni Watershed, Central Highland of Ethiopia. Journal of Culitivated Science 5(2): 134-144.

Taddesse Kippe (2002). Five Thousand Years of Sustainability? A Case Study on Gedeo Landuse(ed) world soil erosion and conservation. Cambridge University Press. Cambridge. (Southern Ethiopia). Doctoral Thesis, Treemail publishers, Heelsum, The Netherland. 295pp.

Tekalign Mamo (1991). Soil, plant, water, fertilizer, animal manure and compost analysis. Working Document No. 13. International Livestock Research Center for Africa, Addis Ababa.

Teklu Erkosa., Asefa, G. and Stahr, K. (2004). Land preparation methods efficiency on the highland Vertisols of Ethiopia. Journal of Irrigation and Drainage Journal 53(1): 69-75.

Uksek, T.Y., Kurdo glu, O. and Uksek, F.Y. (2010). The effects of land use changes and management types on surface soil properties in Kafkas or protected area in Artvin, Turkey, Journal of Land Degradation and Development 21(6): 582-590.

UNESCO/WHO/UNEP (1996). Water quality Assessment a Guide to Use of Biota, Sediments, and water in Environmental monitoring (2 ${ }^{\text {nd }} E d$.)

UNESCO (The United Nations Educational, Scientific and Cultural Organization), (2005). National development report for Ethiopia. UNESCO. World Water Assessment program.

USDA-NRCS (United State Department of Agriculture Natural Resources Conservation Service), (2001). Soil Quality Test Kit Guide. USDA-NRCS Soil Quality Institute, Ames, IA. 82p.
Sci. Technol. Arts Res. J., Jan-March 2016, 5(1): 16-26

US (United State) Salinity Laboratory Staff (1954). Diagnosis and improvement of saline and alkali soils. In: Richards, L.A. (Ed.), Culitivated Handbook No. 60,USDA, U.S. Govt. Printing Office, Washington, D.C. 154-156.

USAID (2004). Ethiopia land policy and administration assessment, Final Report with Appendices (p. 110), USAID Contract No. LAG-00980003100, Task No. 4.

Vityakon, P. (2007). Degradation and restoration of sandy soils under different culitivated land uses in northeast Thailand: a review. Land degradation and Development 18(5):567- 577

Walkley, A. and Black, C.A. (1934). An examination of the Degtjareff method of determining soil organic matter and a proposed modification of chromic acid titration method. Soil Science 37: 29-38.

Wakene Negassa (2001). Assessment of important physicochemical properties of Nitisols under different management systems in Bako Area, western Ethiopia. A Thesis submitted to School of Graduate Studies, Alemaya University, Ethiopia. 93p.

Wakene Negassa and Heluf Gebrekidan (2003). Forms of phosphorus and status of available micronutrients under different land-use systems of Alfisols in Bako Area of Ethiopia. Ethiopian Journal of Natural Resources 5:17-37.

Wakene Negassa and Heluf Gebrekidan (2004). Impact of Different Landuse Systems on Soil Quality of Western Ethiopian Alfisols. A Paper presented on International Research on Food Security, Natural Resource Management and Rural Poverty Reduction through Research for Development and Transformation in Tropentag 2004, October 57, 2004, Berlin, Germany.

Yifru Abera and Taye Belachew (2011). Effects land use on soil organic carbon and nitrogen in soils of Bale, South Eastern Ethiopia. Journal of Tropical and Subtropical Agroecosystems 14: 229-235.

Yihenew Gebresilase and Getachew Ayana (2013). Effects of different land use systems on selected physicochemical properties of soils in Northern Ethiopia. Journal of Culitivated Science 5(4): 112-120.

Yimer, F., Ledin, S. and Abdlkadir, A. (2006). Soil property variations in relation to topographic aspect and vegetation community in the south-eastern highland of Ethiopia, Journal of Natural forest Ecology and Management 232(1): 90-99.

Yimer, F., Ledin, S. and Abdlkadir, A. (2007). Changes in soil organic carbon and total nitrogen contents in three adjacent land use types in the Bale Mountains, southeastern highland of Ethiopia, Journal of Natural forest Ecology and Management 242(2): 337-342.

Yimer, F., Ledin, S. and Abdlkadir, A. (2008). Concentrations of exchangeable bases and cation exchange capacity in soils of cropland, grazing and natural forest in the Bale Mountains, Ethiopia, Journal of Natural forest Ecology and Management 256(6):1298-1302.

Yousefifard, M., Khademi, H. and Jalalian, A. (2007). Decline in soil quality as a result of land use change in Cheshmeh Ali region (IRAN). Journal of Agriculture Science and Natural Resources 14(1): 425-436.

Zeleke Tadesse and Kibebew Kibret (2009). Characterization of the Existing Soil Management Groups in terms of their Physical and Hydraulic Properties at Metahara Sugarcane Plantation.Proceeding. Ethiopian Sugar. Industry Biannual Conference 1: 93-104. 